\title{
FARM CREDITS THROUGH FARMERS' LOAN ASSOCIATIONS
}

\author{
By ISAAC ROBERTS, \\ Author of Looking Forward, Philadelphia.
}

As our farmers put in practice permanent and conservative and soilbuilding methods of agriculture, they will ask and deserve billions of dollars in long-time loans to properly carry out that work, and put agriculture in the United States where it belongs, and is to be: . . . . and long-time amortizing mortgage-loan systems must be devised to give such methods of agriculture the credit facilities and rates they will require and deserve.-From an address by Mr. B. F. Harris, before the Indiana Bankers Association at Indianapolis, Ind., October 16, 1912.

Among the many agencies working to bring about improved social conditions, probably none has greater promise of good results than the present movement to make it possible for the American farmer to obtain financial accommodation at moderate rates of interest, as readily and with as little question as the successful manufacturer and merchant can now secure the accommodation they frequently require. It is to the credit of our people, and especially of that class from whom such accommodation is usually sought-the bankers - that they have for some time past been giving more and more attention to this problem. Many have been studying it here at home. Commissions have gone abroad to study foreign methods of extending such credit, and no doubt plans for doing so here will shortly be presented as the subject of legislation, both by the several states as well as by the national legislature.

It may be well to glance at the pressing needs of the American farmer, before discussing the method of meeting them. Listed in the order of their relative importance these may be stated as follows: the farmer has need of credit (cash) for: (1) the maintenance and improvement of the fertility of the soil; (2) making and maintaining good roads, in order to make markets available; (3) improved machinery and farm equipment including auto-wagons; (4) improving farm buildings, with first attention to the home; (5) providing better schools, courses of lectures, with first attention to scientific farming, and for general social uplift. 
To many minds it may occur the the last-mentioned need should be in the first place, as the needs of the boys and girls are paramount and education should claim the first attention. But if the farm itself is to remain as a producer, providing the living for the boys and girls, the fertility of the soil must be maintained. Its maintenance and improvement thus become a problem of the greatest importance even for the sake of the boys and girls themselves.

As illustrating the second need, that of good roads, so as to make markets available, the fact may be referred to that farm produce has been allowed to waste in the fields, almost within sight of some of our large cities, because the charge for transportation was so high as to wipe out all the farmer's return for shipping it. Within the past year the writer has seen, within twenty miles of one of our largest cities, a field containing five or six acres in which a thousand fine ripe melons were lying, dead ripe and beginning to rot; and the owner said that he would allow them to lie there, as they would not pay the cost of transportation to the city near at hand. Other instances of the same kind will doubtless occur to the reader.

Surely something can be done, and should be done, to remedy such conditions. It is not complimentary to our intelligence that in our cities such need for food should exist, and that on our farms a few miles away good food should be going to waste. What more damaging charge of inefficiency and incompetence can be brought against us as a people than such facts show? If we are not able to solve so easy an economic problem as getting wasting food to the hungry mouths so near at hand, it would seem as though a vast deal of gray matter had been generously but unwisely given to many.

The agency that has contributed most to the superior farming conditions in Europe is the extension of credit to the farmers at the times when they most need such help. One of the methods most frequently referred to is that adopted in France, and known as the method of the Crédit Foncier. This is defined as follows:

The French name for a method of borrowing money on the security of landed property which is widely practiced in France and other continental countries. The borrower takes a loan, for which he contracts to make certain annual payments, which are so adjusted as to make provision for the interest and the gradual extinction of the principal, which is fully paid when the term of the contract has been concluded. The contracts are generally made with companies organized for the purpose of loaning their capital in this manner. - New International Encyclopedia, edition of 1905. 


\section{The American Building and Loan Association System}

From the above definition of the work of the Crédit Foncier, those who are familiar with the working methods of our own building and loan associations will see how close its methods of work are to those of these associations, which have been so successful and have done so much to help build up our towns and cities, and conserve the savings of the people at slight cost and on a purely coöperative basis, with whose operations so many of our people are familiar. It seems to the writer that by a few slight changes, making them more applicable to the needs of our farmers, these well-known methods might well be adopted by our people as the practical solution of the problem of farm credits.

To those who happen to be unacquainted with the plan adopted by the building and loan association it will be sufficient to say that it contemplates the accumulation of a capital (to be lent at the legal rates of interest to those members of the association desiring to borrow it) by the regular monthly payment of certain fixed monthly dues by all the members. To these monthly dues are added the monthly payments for interest, and fines levied for neglect to make payments when due. The usual dues are one dollar per month per share. The usual maturity value of the stock is $\$ 200$ per share, so that the interest per month for each share borrowed on would be one dollar. When the interest is at the rate of 6 per cent, the stock will generally reach its maturity value in about twelve years. The amount paid in at the monthly meetings is usually put up at auction, and the member bidding the most for his loan is awarded the amount desired, subject to the approval of the security offered by a committee appointed for that purpose.

By applying this general plan to the needs of the American farmer we gain the advantage of using a method that is well-known to very many of our people and that is readily understood. Because of this, and because it has demonstrated its usefulness to our people it seems to be an available method, ready for use, and requiring only slight changes to make it fully applicable to the further needs of our farmers. 


\section{Adjustable Difficulties of the Building Association Method}

The chief difficulty in adjusting the usual method of work of the building and loan association arises from the fact that this contemplates the regular monthly payment of dues, and for the average farmer this would be difficult, if not impossible. As a general rule the returns from farming come in or near harvest time; say, in the three fall months of the year; while his need for ready money is concentrated about seed time and in the midst of the harvest, thus distributing his need for money more or less over the other nine months.

It would seem that this difficulty could be readily met by having at least three kinds of stock in the farmers' loan associations, as these organizations might be called, although farmers' building and loan associations would also make a good title. The stock could consist of full-paid stock, upon which interest at not over the legal rate might be allowed; regular stock, to be paid for in the usual way by monthly instalments; and term stock, to be paid for at certain periods, as agreed upon when the stock is at first subscribed for, and the loans made upon this class of stock to be repaid, with interest, also at certain fixed periods.

By arranging for these three kinds of stock, several objects would be attained: In the first place, those subscribing for the fullpaid stock would be furnishing at once a considerable capital, which could be lent out on approved real estate security to those who wished to borrow on the other two kinds of stock; and again,the great difficulty in the way of the farmer making regular monthly payments on account of his stock, and in repayment of his loan is removed. It would be an easy matter to so adjust the interest to the terms of payment as to work no injustice to any other interest in the stock. By allowing for the full-paid stock in the manner suggested, it would also be possible for banks and trust companies to take a moderate holding in such associations, provided the national bank act could be so amended as to permit of such a stock holding. This is suggested as being a quick means of providing capital at the beginning of such associations.

One great advantage of the building and loan association method is that the directors are usually the best-known business men of the community, thus inspiring confidence, attracting business, and bring- 
ing to the active direction of the association very definite knowledge of most of the members of the association-their habits, responsibility and so forth. In the suggested farmers' associations this would no doubt be the case, and would have great value as safe-guarding the interest of all the members. It would doubtless be a good idea in these associations to have also one or two towns-people among the directors, especially if the monthly meetings should be held, for the sake of convenience in a town. And if, now and then, a bank director or two could be added to the board, additional strength would result. In most country towns it usually happens that several of the directors of the local bank are farmers, and this has always a good effect. The reverse of this would no doubt prove to be of as great value to the proposed associations.

As an illustration of the possibilities of this plan of adjustment of building and loan association methods to the present needs of our farmers, the experience may be cited of one of these latter associations located in south-eastern Pennsylvania, in a farming community, holding its monthly meetings in the school-house of a small village. Organized about three years ago, on the usual building and loan association plan, its monthly receipts now are in excess of $\$ 1,000$ each month, its loans have been made almost exclusively upon farm properties, and there is a constant demand for the available funds, so that the earnings the past two years have been in excess of six per cent per year. While the loans have heretofore been used for the purpose of erecting farm buildings, or in part-payment for propperties purchased, there can be no good reason why the farmerborrower should not use his borrowed money for any legitimate purpose, just as other borrowers do, provided that he gives approved real estate security for his loan.

A very great advantage of the building and loan association plan is that it provides a safe local place for the investment of the savings of those working on the farm. If the farmer pays his children for little services, as often happens, or if he has hired help, as is frequently inevitable, here will be a safe saving fund, into which a part of these amounts may be invested, thus increasing the fund available for the farmers of the neighborhood when they need it. "Self-help through mutual help" is, as Sir Horace Plunkett has well said in a recent article, the sure method by which financial and social well-being is to come to the American farmer, just as it has come in this way to his cousins abroad. 


\section{Possible Methods of Raising Funds}

Even under existing conditions, and without any change in the present banking laws, it would still be possible for such loan assoeiations to raise the needed funds, if certain emergencies should make this desirable. Many building and loan associations find it frequently desirable to make short time loans at banks and trust companies, so as to have funds in hand and be able to take good mortgage loans, which otherwise they would be compelled to refuse. These loans are usually made on the plain promissory note of the association, after having been duly authorized by the action of the board, which is certified to the bank making the loan. Some years ago it was the custom in certain places for such loans to be secured as collateral loans by the assignment of mortgages held by the associations, but such loans have been questioned, inasmuch as the associations do not possess a full title to the mortgages they take from their members-the members retaining the right of redemption, which is being continually exercised; so that of recent years such loans have usually been made alone on the credit of the borrowing association, and this would seem to be the better practice.

Another method by which funds could be readily raised when this course appears fully advisable in order to accommodate a worthy member and borrower, who could not be otherwise accommodated, would be for two or three of the directors who approve of the loan, to themselves subscribe for enough full-paid stock to make the loan, and then make themselves whole by using this full-paid stock as collateral at the local bank or trust company for a loan in their own names. This course would scarcely ever be pursued, except where the borrowing member was wellknown, and it was the general desire to accommodate him: but such a contingency might happen now and then, and the plan is suggested to show that present laws and banking usage make the raising of money possible, without additional legislation-although the latter might make it more easy for farm credits to be secured. As a feasible means of extending such loans, by the adaptation of methods already well known, the above plan is suggested. 